\title{
Оценка запасов тульских нефтяных залежей Северо-Юрманского месторождения Пермского края
}

\author{
В.И. Набиуллин, Н.Е. Соснин, А.Г. Субботин, Л.В. Мягкова, \\ Т.И. Майорова, Н.В. Попова
}

Открытое акционерное общество «Камский научно-исследовательский институт комплексных исследований глубоких и сверхглубоких скважин» (ОАО «КамНИИКИГС») , 614016, г. Пермь, ул. Краснофлотская, 15 E-mail: kamniikigs@inbox.ru (Статья поступила в редакичию 28 февраля 20152.)

В рамках работ по выявлению неоценённых залежей на разбуренных площадях нераспределенного фонда недр Пермского края проведена оценка запасов тульских нефтяных пластов Тл 2 -а и Тл 2 -б на Юрманской нефтеносной структуре. Возможность подсчёта запасов по этим объектам определяется получением промышленных притоков нефти при их испытании в колонне скважины № 174, наличием обоснованных структурных построений по данным сейсморазведки и глубокого бурения с учётом современных стратиграфических разбивок, изученностью характера выдержанности пластов по площади, обоснованностью высотного положения ВНК, оценкой эффективных нефтенасыщенных толщин пластов по данным переинтерпретации материалов ГИС, изученностью по керну вещественного состава и коллекторских свойств пластов, исследованием физико-химических свойств нефти в глубинных и поверхностных условиях, обоснованностью КИН статистическим методом.

Ключевые слова: нефть, газ, залежь, месторождение, пласт, толщина, переинтерпретация, ГИС, скважина, подсчёт, оценка, категории запасов.

DOI: $10.17072 /$ psu.geol.28.65

При поисковых работах 1992-1993 гг. на Юрманской нефтеносной структуре скважиной № 174 были выявлены две нефтяные залежи в тульских отложениях визейского яруса нижнего карбона (пласты Тл 2-а и Тл 2-б), а также получены притоки воды с нефтью при испытании двух объектов башкирского яруса среднего карбона (пласты Бш 1 и Бш2). Однако запасы на выявленных объектах не подсчитывались, т. к. тульские нефтяные залежи, согласно принятой на тот период геологической модели, оказались незначительными, а башкирские пласты практического значения не имели из-за большой обводнённости притоков нефти. В настоящее время Юрманская нефтеносная структура учитывается в составе фонда продуктивных структур с перспективными запасами, не поставленными на баланс.

В представленной работе уточнено геологическое строение месторождения и выполнен подсчёт запасов по двум нефтяным пластам Тл 2-а и Тл2-б с учётом переинтерпретации материалов ГИС в 2014 г. Месторождение предложено называть Северо-Юрманским. Оценка его проведена в рамках работ, выполненных ОАО «Кам-

(C) Набиуллин В.И., Соснин Н.Е., Субботин А.Г., Мягкова Л.В. и др., 2015 
НИИКИГС» по договору с ФГУП «НВНИИГГ» в 2013-2015 гг. на основании Государственного контракта «Выявление пропущенных залежей на месторождениях и разбуренных площадях нераспределенного фонда недр ВолгоУральской нефтегазоносной провинции с целью вовлечения их в освоение». Возможность подсчёта запасов по указанным двум объектам определяется получением промышленных притоков нефти при испытании обоих пластов в колонне скважины № 174, а также наличием обоснованных структурных построений, изученностью характера выдержанности пластов по площади, достаточной обоснованностью высотного положения ВНК, оценкой по ГИС эффективных нефтенасыщенных толщин пластов, изученностью по керну их вещественного состава и коллекторских свойств, исследованием физикохимических свойств нефти по одной глубинной и двум поверхностным пробам, достаточной обоснованностью КИН по обеим залежам статистическим методом.

Изученное месторождение находится в северо-восточной части Веслянской валообразной зоны, осложняющей строение северо-восточного крыла Бымско-Кунгурской моноклинали. Северная часть Веслянского вала чётко выделяется по кровле тульских терригенных отложений и осложнена Северо-Ёлкинским, ЮжноЛешаковским и Юрманским локальными поднятиями, которые имеют тектоноседиментационное происхождение, связаны с облеканием верхнедевонскотурнейских рифовых массивов и отчётливо выделяются на фоне общего погружения толщи средне-, нижнекаменноугольных и верхнедевонских отложений в северо-восточном направлении. К сводовым участкам этих локальных положительных структур приурочены мелкие нефтяные залежи Северо-Юрманского месторожде-


ные и газовые залежи Юрманского месторождения (пласты $\mathrm{B}_{3} \mathrm{~B}_{4}$, Бш и Тл 2-б$_{\text {). }}$.

Юрманская нефтеносная структура выявлена и подготовлена сейсморазве- дочными работами и структурнопоисковым бурением в 1981-1982 гг. По поверхности трёх основных отражающих горизонтов (ОГ-I - кровля карбонатных пород башкирского яруса $\mathrm{C}_{2} b$, ОГ-II кровля терригенной пачки тульского горизонта $\mathrm{C}_{1}$ tlt, ОГ-ІІІ ${ }^{\Pi}$ - кровля карбонатных пород турнейского яруса $\mathrm{C}_{1} \mathrm{t}$ ) эта структура имеет форму брахиантиклинали северо-восточного простирания, размеры (сверху вниз по разрезу) от $3.7 \times 1.6$ до $4.0 \times 1.4$ км и амплитуду от 60 до 75 м. Отмечается плановое соответствие структурных построений по всем опорным горизонтам и выполаживание структуры вверх по разрезу. По реперу ГКв (сакмарский ярус $\mathrm{P}_{1} \mathrm{~s}$ ) Юрманская структура не прослеживается, по реперу III (тиманский горизонт нижнефранского подъяруса) Юрманское поднятие вырождается в структурный мыс.

По кровле нефтяного пласта Тлг-а Юрманская структура представляет собой брахиантиклиналь северо-восточного простирания (рис. 1), которая имеет овальную в плане форму, немного расширяющуюся с юго-запада на северо-восток. Размеры структуры по замкнутой изогипсе -1640 м составляют 2.9×0.88-1.14 км, амплитуда 23.6 м. По кровле нефтяного пласта ТЛ 2-б (рис. 2) размеры структуры по замкнутой изогипсе -1660 м немного увеличиваются до 3.0×0.94-1.2 км, амплитуда составляет 24.6 м. В поперечном сечении Юрманское поднятие является асимметричным (рис. 3) и имеет более крутое северо-западное крыло (от $13^{\circ}$ в южной половине структуры до $7^{\circ}$ в северной) и пологое юговосточное крыло (от $5^{\circ}$ в южной половине до $6^{\circ} 38^{\prime}$ в северной). Юго-западная периклиналь антиклинали характеризуется более крутым погружением шарнира под углом $3^{\circ} 48^{\prime}$. На северо-восточной периклинали шарнир погружается под углом $2^{\circ} 34^{\prime}$.

Нефтяная залежь пласта Тл2-а выявлена при испытании верхней части тульского горизонта в колонне скважины № 174 . Испытания проведены эрлифтом в интервале $1837 \ldots 1841$ м (-1632...-1636 м) на двух режимах без предварительного воз- 


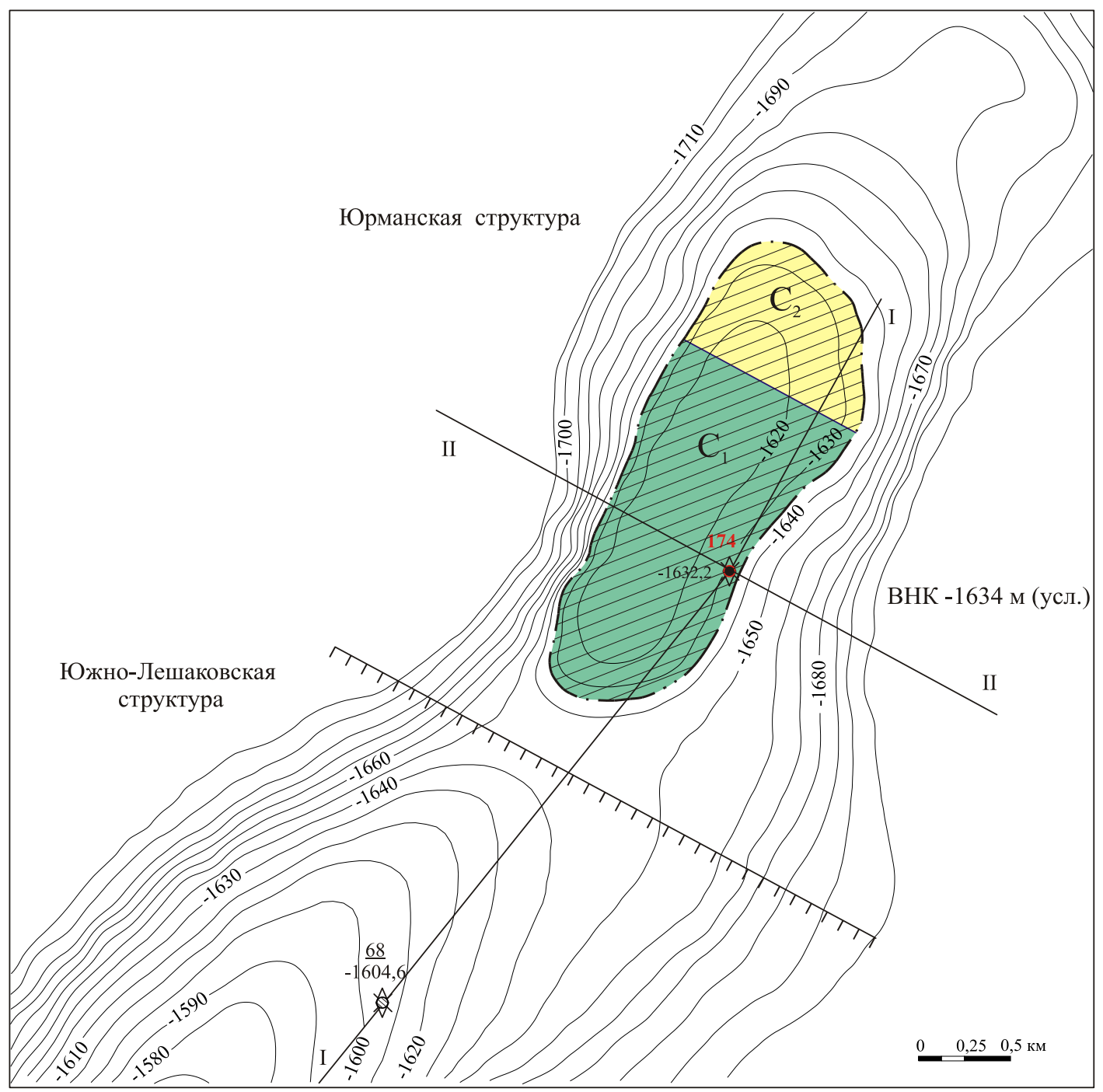

Условные обозначения:

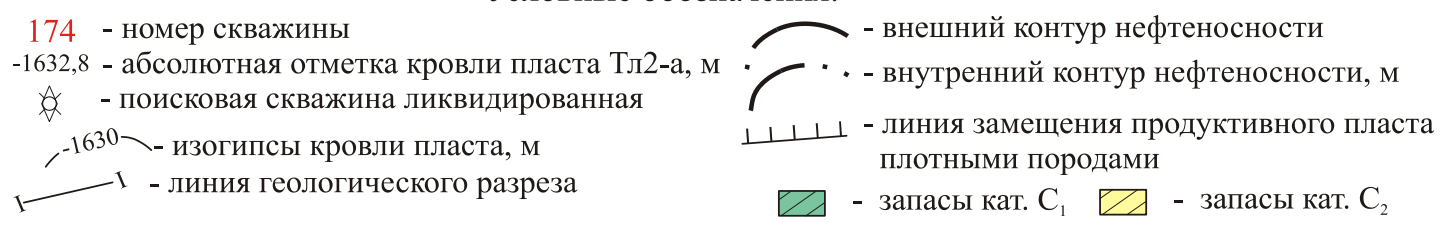


стоянию на 1.11.2014 г.

действия на пласт. При этом получены притоки безводной нефти дебитом $1.74 \ldots 0.85$ т/сут на первом режиме и $1.74 \ldots 1.08$ т/сут на втором режиме при пластовом давлении 18.0 МПа на глубине 1837 м, забойном давлении $0.21 \ldots 3.64$ и $0.19 \ldots 3.53$ МПа и депрессии от 14.47 до 17.8 МПа. Коэффициент продуктивности по нефти составил 0.099 (т/сут)/МПа. Приток нефти в скважину происходил только при забойных давлениях ниже давления насыщения за счёт развития режима растворённого газа. Поэтому параметры оптимального режима работы скважины определены в расчёте на максимальное снижение динамического уровня до 1020 м: дебит нефти 1.2 т/сут, газа $160 \mathrm{~m}^{3} /$ сут при Рзаб = 6.0 МПа на глубине 1837 м. 


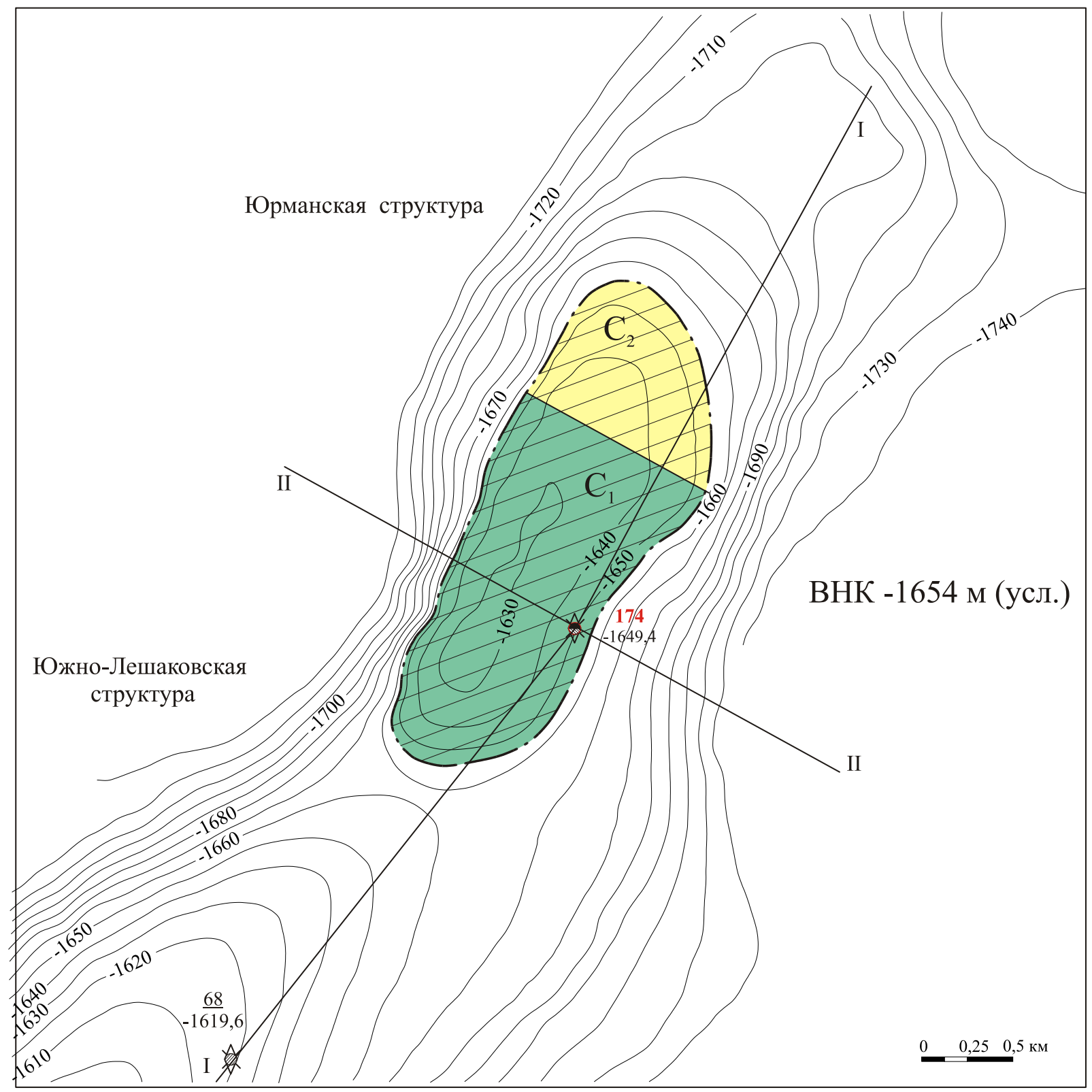

Условные обозначения:

174 - номер скважины -1649,4 - абсолютная отметка кровли пласта Тл2-б, м

\&. - поисковая скважина ликвидированная ,-1630 - изогипсы кровли пласта, м

- внешний контур нефтеносности ' - - внутренний контур нефтеносности, м - линия геологического разреза - запасы кат. $\mathrm{C}_{1} Z \Delta$ - запасы кат. $\mathrm{C}_{2}$

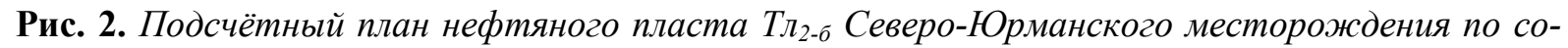
стоянию на 1.11.2014 2.

При переинтерпретации в 2014 г. материалов ГИС по скважине № 174 пласт Тл 2-а выделен в интервале $1837.8 \ldots 1846.2$ м (-1632.2..-1640.6 м). Покрышкой его являются аргиллиты и глинистые алевро- литы верхней части тульской терригенной пачки толщиной 3.8 м, которые перекрыты известняками карбонатной пачки тульского горизонта толщиной 12 м. Продуктивная часть пласта представлена одним 
проницаемым слоем пористых песчаников и алевролитов эффективной толщиной 2.0 м, которые являются нефтенасыщенными в интервале $1837.8 \ldots 1839.8$ м (-1632.2... -1634.2 м) (рис. 3, 4). Ниже этого слоя в интервале $1839.8 \ldots 1846.2$ м залегает пачка переслаивающихся плотных песчаников и алевролитов толщиной 6.4 м, которые входят в состав пласта Тлге-а но не являются коллекторами. Эффективная толщина пласта Тл2-а по скважине № 174 составила 2.0 м при общей его толщине 8.4 м, эффективная нефтенасыщенная толщина - 2.0 м, коэффициент расчленённости 1 и коэффициент песчанистости - 0.24. Водонефтяной контакт принят условно на абсолютной отметке -1634 м по подошве нефтенасыщенного по ГИС слоя с учётом опробования в колонне (рис. 1, 3, 4).
Нефтяная залежь пласта Тлг-б выявлена при испытании нижней части тульского горизонта в колонне скважины № 174. Испытания проведены в интервале глубин $1854.0 \ldots 1856.5$ м (-1649.0..-1651,5 м) на четырех штуцерах диаметрами 7, 3, 5 и 1 мм без предварительного воздействия на пласт. При этом получены промышленные фонтанные притоки нефти дебитом от 1.6 (штуцер 1 мм) до 6.9 т/сут (штуцер 3 мм), пластовой воды дебитом соответственно от 0.22 до 0.58 т/сут и газа дебитом от 1555 (штуцер 3 мм) до 10860 м $^{3} /$ сут (штуцер 7 мм) при пластовом давлении 19.4 МПа на глубине 1855 м, забойном давлении от 18.62 до 12.6 МПа и депрессии от 0.78 до 6.8 МПа. Обводнённость притока нефти
OT 5.6

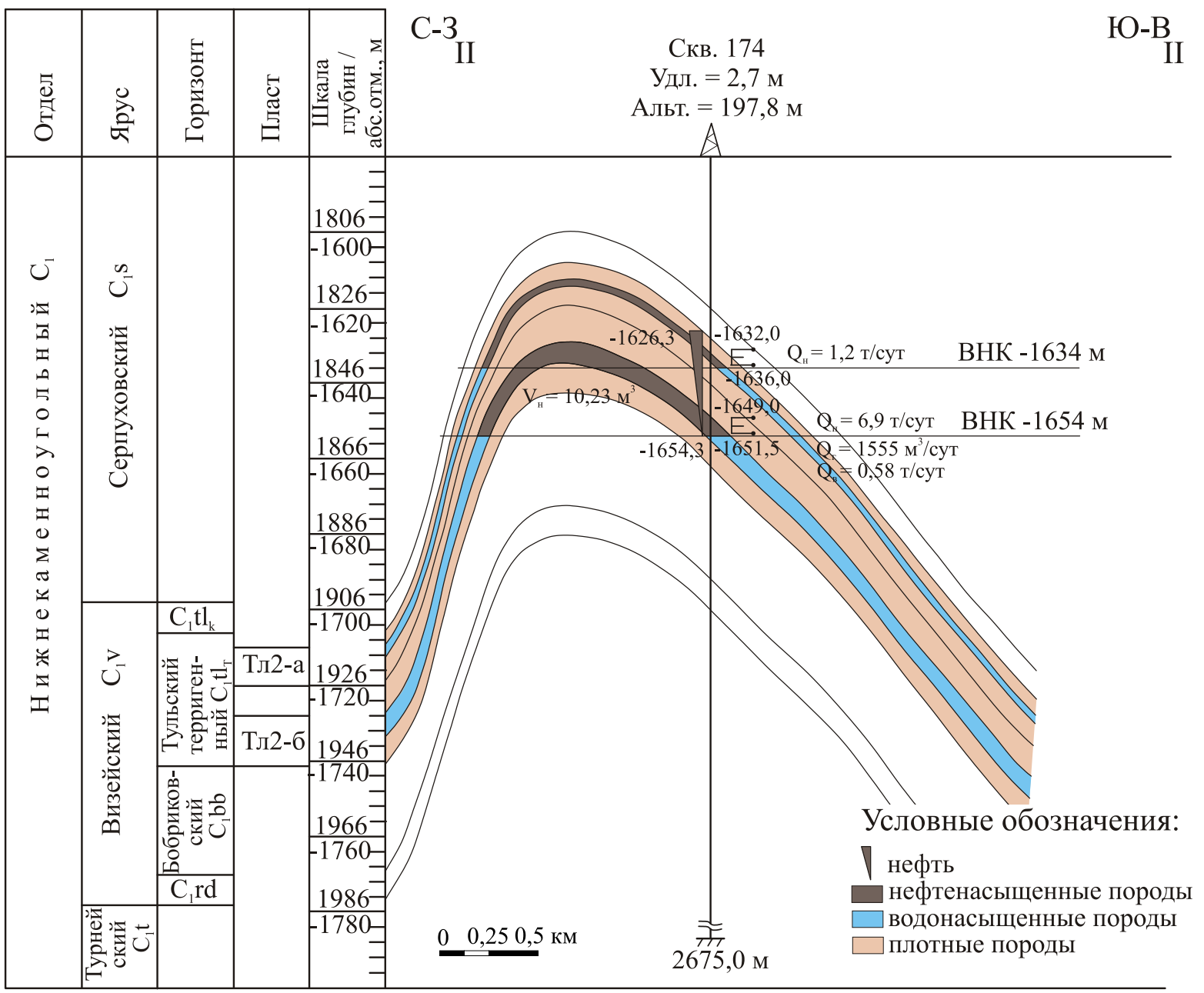

Рис. 3. Поперечный геологический разрез пластов $T_{2-a}$ и Тл $\pi_{2-\sigma}$ Северо-Юрманского месторождения по линии II-II через скважину № 174 


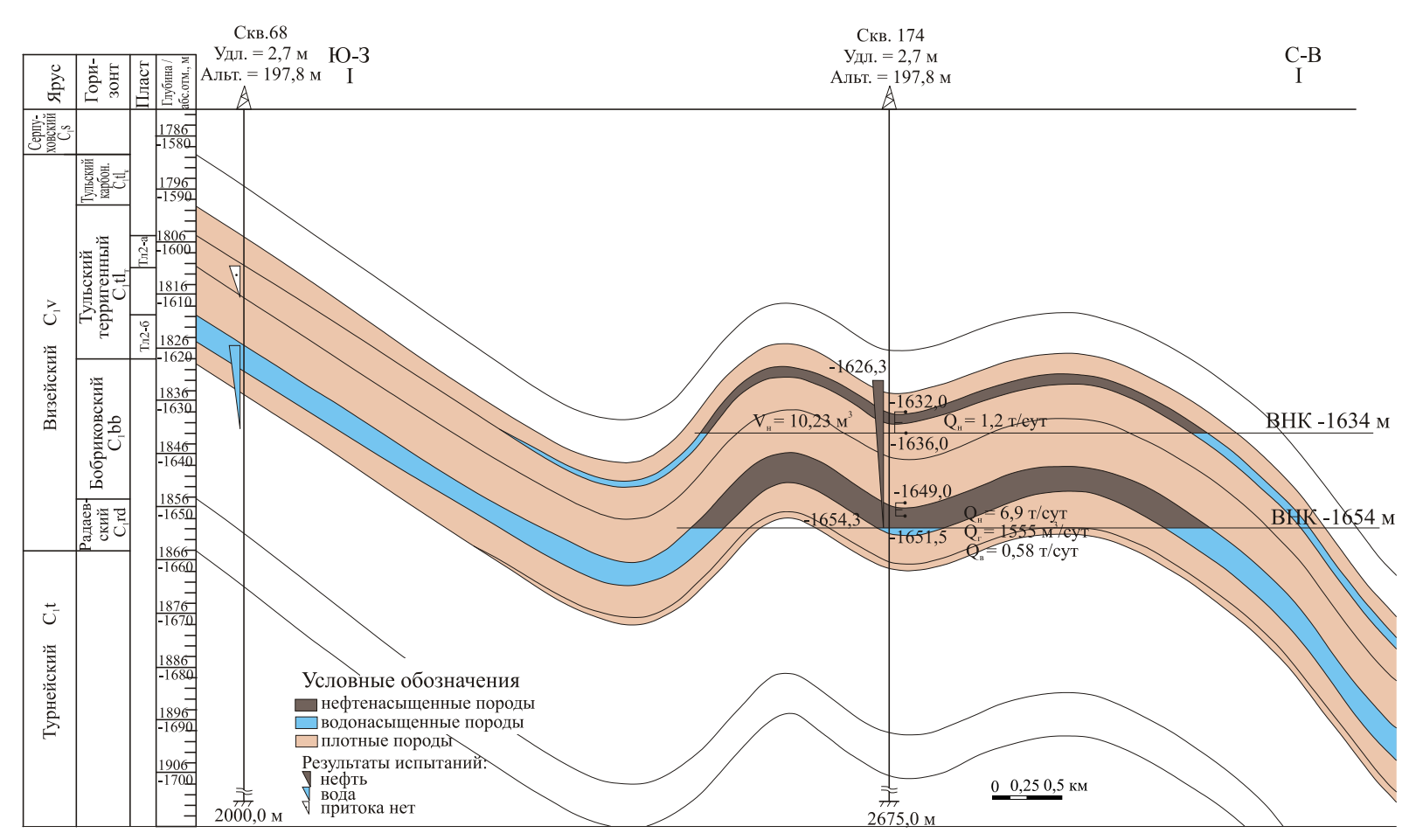

Рис. 4. Продольный геологический разрез пластов $Т_{2-a}$ и $T_{\pi_{2-\sigma}}$ Северо-Юрманского месторождения по линии I-I через скважины № 68-174

до $8.9 \%$, газонасыщенность составила 215 $\mathrm{M}^{3} / \mathrm{T}$, коэффициент продуктивности по нефти был равен 3.56 (т/сут)/МПа, по жидкости - 5.35 (т/сут)/МПа. В качестве оптимального принят режим для допустимо безводной работы скважины на штуцере диаметром 3 мм: дебит нефти 6.9 т/сут, пластовой воды 0.58 т/сут и газа $1555 \mathrm{~m}^{3} /$ сут при Рзаб = 17.55 МПа, Рбуф = 2.88 МПа, Рпл $=19.4$ МПа, Рнас $=19.4$ МПа и депрессии - 1.85 МПа.

При переинтерпретации в 2014 г. материалов ГИС по скважине № 174 пласт Тл 2-б выделен в интервале 1855.0...1866.2 м (-1649.4...-1660.6 м). Покрышкой его являются аргиллиты и глинистые алевролиты междупластия Тл 2-а - Тл$_{2-б}$ толщиной 8.8 м в средней части тульского горизонта. Пласт Тл м (-1649.4... -1655.2 м) сложен пористыми песчаниками и алевролитами эффективной толщиной 5.8 м (рис. 3,4$)$. По данным ГИС верхняя часть этого интервала толщиной 4.2 м является нефтенасыщенной, а нижняя часть толщиной 1.6 м - водонасыщенной. Водонефтяной контакт принят условно на абсолютной отметке -1654 м по данным ГИС с учётом опробования в колонне (рис. 3, 4). Ниже водонасыщенного слоя в интервале 1860.8...1866.2 м залегает пачка переслаивающихся плотных песчаников и алевролитов толщиной 5.4 м, пласта Тлг-б, но не являются коллекторами (рис. 4).

Эффективная нефтенасыщенная толщина пласта Тлгеб в скважине № 174, расположенной на юго-восточном крыле Юрманской структуры, составила 4.2 м при общей его толщине 11.2 м и эффективной толщине 5.8 м. В сводовой части структуры и в пределах внутреннего контура нефтеносности эффективная нефтенасыщенная толщина пласта составляет 5.8 м (рис. 3). Коэффициент песчанистости по пласту равен 0.52 , коэффициент расчленённости - 1. Пласт Тл 2-б в скважине № 174 подстилается слоем аргиллитов толщиной 1.8 м, которые залегают в основании тульского горизонта в интервале $1866.2 \ldots 1868.0 \mathrm{M}$.

Нефтяные залежи пластов Тл 2 -а $и$ Тл отнесены к типу пластовых сводовых. Размеры залежей в пределах принятых ВНК составляют $2.7 \times 0.95$ и $2.85 \times 1.0$ км 
(рис. 1, 2), высоты в своде структуры 23.6 и 24.6 м, глубины залегания кровли пластов в своде антиклинали - 1818 и 1835 м, а на юго-восточном крыле структуры в скважине № $174-1837.8$ и 1855 м (рис. 3). Площади залежей равны 2254 и 2447 тыс. $\mathrm{M}^{2}$, средневзвешенные нефтенасыщенные толщины 1.9 и 5.2 м.

Подсчётные планы залежей (рис. 1, 2) построены по данным сейсморазведки, поисковой скважины № 174 и ближайших глубоких скважин соседних месторождений - Юрманского (скважина № 68) и Ильичёвского (скважины № 161, 163) с учётом современных стратиграфических разбивок. Структурные построения выполнены достаточно обоснованно и позволили уточнить структурный план Юрманской структуры по кровле обоих нефтяных пластов.

При анализе выдержанности нефтяных пластов по простиранию Юрманской структуры использованы данные ГИС и результаты испытаний тульского и бобриковского пластов в колонне скважины № 68 соседнего Юрманского месторождения, а также схема выделения коллекторов по пластам Тл 2-а и Тл 2-б в скважине № 174. Анализ материалов показал, что в юго-западном направлении от скважины № 174 нефтенасыщенный проницаемый слой Северо-Юрманского пласта Тл 2 -а становится водонасыщенным за пределами внешнего контура нефтеносности, а затем выклинивается между скважинами № 174 и 68 (рис. 1, 4). На площади Юрманского месторождения он замещается плотными непроницаемыми породами. При испытании в колонне скважины № 68 аналога пласта Тл 2-а притока не получено.

Что касается нефтенасыщенного проницаемого слоя Северо-Юрманского пласта Тл 2-б, то в юго-западном направлении от скважины № 174 он становится водонасыщенным за пределами внешнего контура нефтеносности и в районе скважины № 68 увязывается с водонасыщенным интервалом нижней части тульской терригенной пачки (рис. 4). При испытании этого интервала в колонне скважины № 68 получен приток пластовой воды. При этом нижняя непроницаемая часть СевероЮрманского пласта Тлг-б увязывается с интервалом непроницаемых плотных и крепких аргиллитов и глинистых алевролитов в основании тульской терригенной пачки в скважине № 68.

При анализе выдержанности обоих нефтяных пластов Тл 2-а и Тлг-б вкрест простирания Юрманской структуры учитывалось, что в скважине № 161 Ильичёвского месторождения, расположенной к северозападу от Северо-Юрманского месторождения, при испытании терригенной пачки тульского горизонта в открытом стволе приток получен не был, а в Ильичёвской скважине № 163 тульский горизонт не был опробован.

Коллекторы обоих пластов относятся к поровому типу, представлены песчаниками средне- и мелкозернистыми, слабоглинистыми и алевролитами крупнозернистыми, глинистыми. Открытая пористость терригенных коллекторов по 17 определениям из керна изменяется от 8.3 до 19.5 $\%$, средняя - $11.9 \%$, проницаемость по 16 керновым определениям - от 0.001 до 0.392 мкм $^{2}$, средняя -0.0437 мкм $^{2}$. При переинтерпретации в 2014 г. материалов ГИС по продуктивной части пластов Тл2-а

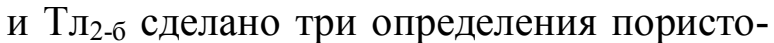
сти (соответственно 11.7 и 16.5, $16.5 \%$ ) и по одному определению нефтенасыщенности (92 и 86 \%). Для подсчёта запасов приняты значения пористости и нефтенасыщенности по данным ГИС из-за отсутствия определений нефтенасыщенности по керну.

Физико-химические свойства нефти изучены по двум поверхностным пробам из пластов Тл 2-а $_{\text {и }}$ Тл $_{2-б}$ и одной глубинной пробе из пласта Тл 2-б, отобранным в скважине № 174. В поверхностных условиях


сернистая, смолистая, парафинистая, обогащена бензинокеросиновыми компонентами, а нефть пласта Тле-б - лёгкая, маловязкая, сернистая, малосмолистая, высокопарафинистая, также обогащена бензинокеросиновыми компонентами. В пла- 
стовых условиях нефть пласта Тлгеб легкая, маловязкая, содержание газа составляет $215 \mathrm{~m}^{3} / \mathrm{T}$, объёмный коэффициент 1.385 .

Подсчёт запасов двух тульских нефтяных залежей выполнен объёмным методом по данным скважины № 174 по состоянию на 01.11.2014 с учетом требований действующей классификации ГКЗ [1, $2,3,5]$. Принятый метод подсчёта соответствует особенностям геологического строения и степени изученности СевероЮрманского нефтяного месторождения. По фазовому состоянию месторождение относится к группе нефтяных, а по величине запасов - к группе очень мелких месторождений с извлекаемыми запасами нефти менее 1 млн т [1]. Продуктивные пласты обеих залежей характеризуются достаточной степенью выдержанности литологического состава, толщин и коллекторских свойств в пределах Юрманской нефтеносной структуры, поэтому месторождение следует отнести к группе простого строения. Вместе с тем за пределами месторождения, на участке между Юрманской и Южно-Лешаковской структурами, происходит общее уменьшение толщины терригенной пачки тульского горизонта, выклинивание продуктивного пласта Тл 2-а и литологическое замещение коллекторов этого пласта непроницаемыми породами в юго-западном направлении (рис. 4). В целом обоснованность подсчётных параметров по обоим нефтяным пластам Тл 2-а и Тл 2-б можно считать достаточной для данной стадии их изучения.

При подсчёте запасов нефти согласно требованиям действующей классификации ГКЗ $[1,2]$ к категории $\mathrm{C}_{1}$ на обеих залежах отнесены площади нефтеносности в зоне дренирования поисковой скважины № 174, в которой получены промышленные притоки нефти дебитом 1.74...1.08 т/сут из пласта Тлге-а, а из пласта Тл фонтанный приток нефти 6.9 т/сут и пластовой воды 0.58 т/сут на штуцере диаметром 3 мм. Эти площади ограничены условными линиями, ориентированными в северо-западном направлении вкрест преобладающего простирания структуры и проходящими на расстоянии удвоенного радиуса дренажа (1000 м) к северо-востоку и юго-западу от скважины. При этом юго-восточная, юго-западная и северо-западная границы площади категории $\mathrm{C}_{1}$ совмещены с внешним контуром нефтеносности (рис. 1, 2), а северо-восточная граница совпадает с линией, проведённой вкрест простирания брахиантиклинали на расстоянии 1000 м к северо-востоку от скважины № 174.

Площади нефтеносности категории $\mathrm{C}_{2}$ на обеих залежах выделены на северо-восточном периклинальном замыкании антиклинали между контурами запасов категории $\mathrm{C}_{1}$ и границами залежей, которые совмещены с внешним контуром нефтеносности (рис. 1, 2).

Границы запасов категории $\mathrm{C}_{1}$ выделены на основании следующих признаков: 1) по данным скважины № 174 установлено положение продуктивных пластов Тл2-а и Тл $л_{2-б}$ в разрезе, а с учетом ближайших глубоких скважин соседних нефтяных месторождений (Юрманского и Ильичёвского) оценена выдержанность пластов по площади; 2) получены промышленные притоки нефти и определены начальные дебиты при испытании пластов Тл 2 -а и Тл 2-б в колонне скважины № 174; 3) высотное положение ВНК в достаточной степени обосновано данными опробования и ГИС; 4) изучен вещественный состав продуктивных пластов, определены их общие и эффективные нефтенасыщенные толщины; 5) коллекторские свойства пород продуктивных пластов оценены по керну и промыслово-геофизическим данным с использованием петрофизических зависимостей «керн-ГИС»; 6) физикохимические свойства нефти изучены по двум поверхностным пробам из пластов Тл 2-а и Тлгеб и одной глубинной пробе из пласта Тлгб-б; 7) газосодержание нефти и пересчётный коэффициент при подсчёте запасов по обоим пластам приняты по данным анализов глубинной пробы нефти из пласта Тлгеб; 8) выполнено обоснование 
КИН по пластам Тл 2 -а $и$ Тл ванием статистического метода $[4,6]$.

Для подсчёта запасов приняты следующие значения подсчётных параметров. По пласту Тл2-а площади нефтеносности по категориям $\mathrm{C}_{1}$ и $\mathrm{C}_{2}$ - соответственно 1642 и 612 тыс. м², средневзвешенные эффективные нефтенасыщенные толщины - 1.9 и 1.8 м, нефтенасыщенные объёмы 3061 и 1128 тыс. м ${ }^{3}$. По пласту Тл2-б площади нефтеносности по категориям $\mathrm{C}_{1}$ и $\mathrm{C}_{2}-1758$ и 689 тыс. м², средневзвешенные эффективные нефтенасыщенные толщины - 5.3 и 4.8 м, нефтенасыщенные объёмы - 9359 и 3326 тыс. м³. Значения коэффициентов пористости и нефтенасыщенности приняты по данным ГИС: пористости - 0.12 по пласту Тл 2 -а $и$ 0.16 по пласту Тл 2-б, нефтенасыщенности - соответственно 0.92 и 0.86 . Плотность нефти в стандартных условиях - $0.858 \Gamma / \mathrm{cm}^{3}$ по

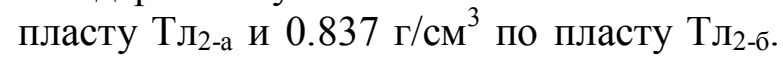
По обоим пластам пластовый газовый фактор принят равным $215 \mathrm{~m}^{3} / \mathrm{T}$, пересчётный коэффициент 0.722. Для обоснования коэффициентов извлечения нефти использованы метод аналогии и статистический метод $[4,6]$. Значения КИН, оценённые с помощью статистического метода по формуле В.К. Гомзикова, составили 0.374 по пласту Тл

По состоянию на 1.01.2014 СевероЮрманское нефтяное месторождение не учтено Государственным балансом запасов и не принадлежало распределенному фонду недр Пермского края. Запасы углеводородного сырья Северо-Юрманского нефтяного месторождения подсчитаны впервые. Согласно подсчёту, выполненному по состоянию на 1.11.2014, запасы нефти и растворённого газа на площадях каждой залежи, ограниченных водонефтяными контактами, отнесены к категориям $\mathrm{C}_{1}$ и $\mathrm{C}_{2}$ в следующих количествах.

По пласту Тл2-а запасы нефти (геологические / извлекаемые, тыс. т) по категории $\mathrm{C}_{1}-209 / 79$, категории $\mathrm{C}_{2}-78 / 30$, по сумме категорий $\mathrm{C}_{1}+\mathrm{C}_{2}-287$ / 109. Запасы растворённого газа (геологические / извлекаемые, млн ${ }^{3}$ ) по категории $\mathrm{C}_{1}-45$
/ 17, категории $\mathrm{C}_{2}-17$ / 7, по сумме категорий $\mathrm{C}_{1}+\mathrm{C}_{2}-62$ / 24.

По пласту Тлг-б запасы нефти (геологические / извлекаемые, тыс. т) по категории $\mathrm{C}_{1}-778 / 325$, категории $\mathrm{C}_{2}-277$ / 116 , по сумме категорий $\mathrm{C}_{1}+\mathrm{C}_{2}-1055 /$ 441. Запасы растворённого газа (геологические / извлекаемые, млн $\mathrm{m}^{3}$ ) по категории $\mathrm{C}_{1}-167 / 70$, категории $\mathrm{C}_{2}-60$ / 25, по сумме категорий $\mathrm{C}_{1}+\mathrm{C}_{2}-227 / 95$.


Юрманского месторождения запасы нефти (геологические / извлекаемые, тыс. т) по категории $\mathrm{C}_{1}-987$ / 404, категории $\mathrm{C}_{2}$ - 355 / 146, по категориям $\mathrm{C}_{1}+\mathrm{C}_{2}-1342$ / 550 ; запасы растворённого газа (геологические / извлекаемые, млн м ${ }^{3}$ ) по категории $\mathrm{C}_{1}-212$ / 87, категории $\mathrm{C}_{2}-77$ / 32, по сумме категорий $\mathrm{C}_{1}+\mathrm{C}_{2}-289$ / 119.

\section{Библиографический список}

1. Временная классификация запасов месторождений, перспективных и прогнозных ресурсов нефти и горючих газов. Утверждена приказом Министерства природных ресурсов Российской Федерации № 126 от 07.02.2001 г. / МПР РФ. М., 2001. 17 с.

2. Классификация запасов и прогнозных ресурсов нефти и горючих газов. Утверждена приказом Министерства природных ресурсов Российской Федерации от 01.11.2005 г. № 298 / МПР РФ. М., 2006. 9 с.

3. Методические рекомендации по применению Классификации запасов и прогнозных ресурсов нефти и горючих газов, утверждённой приказом МПР России № 298 от 01.11.2005 г. / МПР РФ. М., 2006. 22 с.

4. Методическое руководство по расчёту коэффициентов извлечения нефти из недр. РД 39-0147035-214-86 / Б.Т. Баишев, Ю.Е. Батурин, Г.Г. Вахитов и др. / Миннефтепром СССР. М., 1986. 253 с.

5. Требования к составу и правилам оформления представляемых на государственную экспертизу материалов по подсчёту запасов нефти и горючих газов. Утверждены приказом Минприроды России № 34 от 15.02.2011 г. / МПР РФ. М., 2011. 15 c.

6. Чуносов П.И. Методы определения коэффициента извлечения нефти (КИН) при подсчёте запасов / ВНИГРИ. СПб, 2008. 21 c. 


\title{
Estimation of Reserves of Tula Horizon Oil Deposits of Severo-Yurmanskoye Field, Perm Kray
}

\author{
V.I. Nabiullin, N.E. Sosnin, A.G. Subbotin, L.V. Myagkova, \\ T.I. Mayorova, N.V. Popova \\ JSC «Kamskiy Research Institute of Complex Study of Deep and Superdeep \\ Wells» (JSC «KamNIIKIGS»), 15 Krasnoflotskaya Str., Perm 614016, Russia \\ E-mail: kamniikigs@inbox.ru
}

This article presents an estimation of reserves of the Tula horizon oil-bearing layers $\mathrm{Tl}_{2-\mathrm{a}}$ and $\mathrm{Tl}_{2-\mathrm{b}}$ at the Severo-Yurmanskoye oil field. Research was carried out in order to prospect the un-estimated oil reserves at the previously drilled but not commercially producing areas of Perm kray. The opportunity of reserve calculation for this oil field was provided by the sufficient oil encroachment rate achieved during testing of Tula horizon layers in the borehole 174, reliable mapping of oil-bearing horizons using seismic and borehole data, existence of updated stratigraphic information, results of study of uniformity of oil-bearing layers throughout the area of the Severo-Yurmanskoye oil field, reliable estimate of the position of water-oil contact, defining the effective oil-bearing thickness of oil-bearing layers using results of borehole geophysical survey, study of lithological composition and reservoir properties, study of physical and chemical properties of oil in borehole and in laboratory, and reliability of statistical evaluation of oil recovery factor. Key words: oil and gas deposit, layer, thickness, borehole, interpretation, BGS borehole geophysical survey, classification, calculation, assessmen.

\section{References}

1. Vremennaya klassifikatsiya zapasov mestorozhdeniy, perspektivnykh i prognoznykh resursov nefti i goryuchikh gazov [Temporary classification of deposit reserve, perspective and expected resources of oil and combustible gases]. Utverzhdena prikazom Ministerstva prirodnykh resursov Rossiyskoy Federa-tsii No. 126 ot 7.02.2001. M., MPR RF, p. 17. (in Russian)

2. Klassifikatsiya zapasov i prognoznykh resursov nefti i goryuchikh gazov [Classification of reserves and expected resources of oil and combustible gases]. Utverzhdena prikazom Ministerstva prirodnykh resursov Rossiyskoy Federatsii No. 298 ot 01.11.2005. M., MPR RF, p. 9. (in Russian)

3. Metodicheskie rekomendatsii po primeneniyu Klassifikatsii zapasov i prognoznykh resursov nefti i goryuchikh gazov, utverzhdennoi prikazom Ministerstva prirodnykh resursov Rossiyskoy Federatsii No. 298 ot 01.11.2005. 2006. [Methodical recommendations on application of Classification of reserves and expected resources of the oil and combustible gases, assigned by the order of MPR of Russia
01.11.2005 No. 298]. M., MPR RF, p. 22. (in Russian)

4. Metodicheskoe rukovodstvo po raschyotu koeffitsientov izvlecheniya nefti iz nedr [The methodical guide to calculation of oil recovery factor]. RD 39-0147035-214-86. Eds. B. T. Baishev, Yu.E. Baturin, G.G. Vakhitov i drugie. M., Minnefteprom of the USSR, 1986, p. 253. (in Russian)

5. Trebovaniya $\mathrm{k}$ sostavu i pravilam oformleniya predstavlyaemykh na gosudarstvennuyu ekspertizu materialov po podschyotu zapasov nefti i goryuchikh gazov [Requirements to structure and regulations of registration of the materials on oil and combustible gases reserves estimates submitted for state examination]. Utverzhdeny prikazom Ministerstva prirodnykh resursov Rossiyskoy Federatsii No. 34 ot 15.02.2011. M., MPR RF, p. 15. (in Russian)

6. Chunosov P. I. 2008. Metody opredeleniya koeffitsienta izvlecheniya nefti (KIN) pri podschyote zapasov [Methods of determination of the oil recovery factor (ORF) for reserve calculation]. Sankt-Peterburg, Vserossiyskiy neftyanoiy nauchno- issledovatelskiy institut (VNIGRI), p. 21. (in Russian) 